\title{
Is the Export-Led Growth Hypothesis Valid for Sri Lanka? A Time-Series Analysis of Export-Led Growth hypothesis
}

\author{
W.A. Dilrukshini ${ }^{1}$
}

\begin{abstract}
This study examines the validity of the export-led growth hypothesis (ELG) for Sri Lanka using annual data over the period 1960-2005, employing time-series analysis techniques of cointegration, causality, Vector Auto Regressions (VARs) and Impulse Response Functions (IRFs). This study controls for other macroeconomic variables that might have a significant effect on export-economic growth relationship. The findings do not provide empirical support for the export-led growth hypothesis for Sri Lanka.
\end{abstract}

\section{Introduction}

The relationship between export growth and economic growth has long been one of the major areas concerned in the theoretical and empirical literature in international trade and development economics. These highlight the importance of export promotion to achieve higher economic growth. Early studies, cross-country as well as time-series analysis, examined the relationship between export growth and economic growth, looking at simple correlation relationships (eg: Balassa 1978, 1985, Kravis 1970). The problems of their methodology were that it does not provide the indication of directional relationships: whether export growth causes economic growth or economic growth causes export growth. Cross-country regressions, in particular, do not capture the dynamics of the relationships between export and economic growth and pay no attention to country-specific factors. Though many, particularly the neoclassical views, suggest with empirical evidences that export growth causes economic growth (i.e. the export-led growth hypothesis), there are still some, who do not believe the export-led growth hypothesis. This present study on export and economic growth employs cointegration technique and causality testing to identify the two-way directional relationships in Sri Lankan context. Moreover, VARs and IRFs are employed to examine the impact of economic shocks.

This study is different from earlier work done on Sri Lanka for mainly three reasons. First, the study tested the ELG hypothesis while controlling for other macroeconomic variables that might have a significant effect on export-economic growth relationship. Second, the study went beyond the earlier two-variable relationship

\footnotetext{
${ }^{1}$ The author wishes to thank Dr. Tom Kompas and Dr. Satish Chand (Australian National University) for their valuable comments and guidance throughout this study. The views expressed in this paper are the author's own and do not necessarily reflect those of the Central Bank of Sri Lanka.
} 
analyses by employing a VAR model. Third, the study also employed IRFs to investigate the impact of economic shocks. None of the earlier work has employed IRFs on Sri Lanka to analyze ELG hypothesis.

The purpose of this paper is to examine the export-led growth hypothesis by analyzing the relationship between exports and economic growth in Sri Lanka during the period 1960-2005, employing recently developed time-series analyses techniques including cointegration and causality, VAR and IRFs.

The rest of the paper organizes as follows: Section 2 presents the literature review, and the analytical framework is presented in section 3. It follows the methodology and data section, which includes source of data and econometric methods employed in the study. Section 5 presents empirical results. Finally, concluding remarks and policy implications are presented in section 6 .

\section{Literature Review}

The relationship between exports and economic growth has been discussed by many economists and the application of the ELG paradigm was given much attention with the surfacing of the East Asian Tigers. The ELG theory has been analyzed as cross section analyses (eg: Balassa 1978, 1985, Ekanayake 1999, Feder 1983, Jin 1995, Michaely 1977, Tyler 1991) as well as country specific analyses using time-series data (eg: Botho 1996, Chow 1987, Islam 1998, Ram 1985, Shan and Sue 1998,) with mixed results in the past three decades. Among them recent studies (Abou-Stait 2005, Awokuse 2003, Ekanayake 1999, Oxley 1993, Shan and Sun 1998, Sharma and Panagiotidis 2005) on export and economic growth have employed cointegration technique and causality testing to identify the ELG hypothesis. Though some studies accept the ELG paradigm, some other studies illustrate suspicions about $i^{2}$. However, their conclusion supports the ELG hypotheses in developing countries in varying degrees.

Balassa (1978), one of the predominant writers in the area of ELG hypothesis, using data for the period 1960-73 for 11 countries finds a positive effect of export growth on economic growth. Balassa (1978) uses correlation and regression analyses to examine the effect of export growth on economic growth. In addition, Feder (1983), and Ram (1985) find empirical evidence for strong cross country association between exports and economic growth. Time series analyses have also supported the ELG hypothesis (eg: Chow 1987, Doyle 1998, Ram 1987, Abou-Stait 2005, Thornton 1996, $\mathrm{Xu}$ 1996).

\footnotetext{
${ }^{2}$ Some found bi-directional relationship (Chow 1987, Kunst and Marin 1989), and some found uni-directional relationship (eg: Doyle 1998, Thornton 1996, Xu 1996), while others found no causality (eg: Ahmad and Kwan 1991, Giles and Williams 1999, Jung and Marshall 1985, Shan and Sun 1998, Sharma and Panagiotidis 2005, Sims 1972).
} 
Feder (1983), using a sample of 55 semi-indutralized developing countries, finds that export variable is positive and significant at 5 per cent level. Feder (1983) argues that ELG strategy tends to reallocate the resources in a country from less efficient sectors to more dynamic sectors. According to Feder (1983), the production efficiency of a country can be enhanced through the vibrant export sector. The pressure of world competition leads to better quality products and forces domestic producers to increase efficiency. The increased efficiency and positive externalities (such as improved technical know how, efficient managerial skills etc.) gained from export growth have an impact on the non-export sector supporting to increas the overall output of the economy.

Abou-Stait (2005) argues that exports have a significant impact on economic growth in Egypt in spite of Egypt's higher dependency on imported raw materials. Sun and Parikh (2001) highlight that expansion of exports has a positive and significant impact on economic growth in China. Their study employs Feder model, and concludes that positive externalities generated by the export sector to the non-export sector has increased overall economic growth.

In the case of Sri Lanka, Abhayaratne (1996) and Shirazi and Abdul Manap (2005) find no support for the ELG hypothesis. She analyzed the validity of the ELG hypothesis for Sri Lanka using cointegration and causality techniques. She employed only exports, GDP and imports. Some excluded variables may have misled her findings. However, another cointegration study on Sri Lanka Fernando and Colombage (2002) supports the ELG hypothesis. They employed only real export and real GDP data, which might have misled their findings since they have ignored some of the important variables that have an impact on economic growth.

As noted, empirical investigations on the ELG hypothesis show mixed results. According to Ram (1985), export growth is significant for economic growth. However, the impact of exports on economic growth is less significant for low and high level income countries compared to middle income countries (Kravis 1970, Michaely 1977, Poon 1995, Ram 1985). For exports to effectively affect economic growth, a country should reach a minimum level of development (Yaghmaian and Ghorashi 1995). The authors highlight the importance of a sound process of structural changes. All these indicate that the impact of exports on economic growth depends on the level of economic development and economic structure and the dynamic process of structural changes.

Methodologically, though the cross-country studies on ELG hypothesis are well documented, they implicitly assume that developing countries share common characteristics. This is not true since countries differ in their social, political, institutional, and economic structure and thus in the ways of reactions to external 
shocks. Therefore, cross-country regression analyses can be misleading since they do not take into account country-specific characteristics (Shan and Sun 1998). They do not either capture the dynamics of the relationships between exports and economic growth. On the other hand, apart from the problem of spurious regression with the earlier timeseries regression analyses, some problems with recent time-series studies are highlighted (Bewley and Yang 1996, Giles and Williams 1994, Toda 1994), namely, the arbitrariness in the choice of the lag length, the application of F-statistics to causality test, and model specifications (Chow 1987, Darrat 1987, Ghartey 1993, Hatemi-J and Irandoust 2000, Toda and Yamamoto, 1995).

Choosing the correct variables is a tricky issue. Some earlier studies analyzed ELG hypothesis by employing just exports and GDP - two variable relationships - (for example Fernando and Colombage 2002), while others employed multivariate analytical techniques using other relevant macro economic variables. In some cases, instead of GDP, GDP minus exports (non-export GDP) has been used to avoid the 'national income accounting identity issue' because exports are themselves a component of output (Ghatak et al. 1997, Feder 1983, Love 1992, Sharma and Panagiotidis 2005).

\section{Analytical Framework}

In the literature, causality from exports to economic growth in terms of real output growth is recognized as the ELG hypothesis. According to the ELG hypothesis, export-orientation policies contribute to stimulate economic growth both directly and indirectly through the expansion of the export sector ${ }^{3}$. Export expansion directly accelerates output growth as a component of aggregate output in a country (through the Keynesian multiplier). This indirectly stimulates economic growth through the use of advanced technology, which results in efficient allocation of resources and higher productivity (Balassa 1978, Grossman and Helpman 1991), greater capacity utilization and exploitation of economies of scale (Helpman and Krugman 1985) due to foreign market competition and large markets. In addition, the generation of foreign exchange from exports allows not only for increasing levels of imports but the import of high quality inputs including capital and intermediate goods, which in turn raise domestic production and thus stimulate output growth (Awokuse 2003, Balassa 1978, McKinnon 1964).

\footnotetext{
${ }^{3}$ Moosa (1999) gives three reasons to support this hypothesis. The first reason is that, from Keynsian argument, export growth lead, through the foreign trade multiplier, to output expansion. The second argument is that the accumulation of foreign exchange from exports, which can be used to import capital and intermediate goods, leads in turn to stimulate economic growth. Finally, he argues that competition generates economies of scale and an acceleration of technical progress in production which are important sources of economic growth.
} 
Following early empirical formulation of the new growth framework (Awokuse 2003, Shan and Sun 1998), this study tests the export-led growth hypothesis by expanding the growth equation and including other relevant variables such as real imports, investment, labor, in the production function. Accordingly, the aggregate production function is expressed as:

$$
L R G D P_{t}=f\left(L R E X_{t}, L_{R I M}, L R I N V_{t}, L L A_{t}\right)
$$

where $\mathrm{LRGDP}_{\mathrm{t}}$ represents real GDP in log term, and LREX ${ }_{\mathrm{t}} \mathrm{LRIM}_{\mathrm{t}}, \mathrm{LRINV}_{\mathrm{t}}$, and LLA are real exports, real imports, real investment and labor respectively. All are log terms, and subscript $t$ denotes time.

\subsection{Econometric Method}

The use of time-series analyses, particularly time-series methods on unit-roots and cointegration, to examine the dynamic relationship between export growth and economic growth has attracted considerable attention among economists. This study employs the Granger causality test methodology with cointegration techniques to test the ELG hypothesis. In addition, VARs and IRFs are employed to investigate the impact of economic shocks.

\subsubsection{Test for Non-stationary and Unit Root Tests}

To avoid the problem of spurious regression and the failure to account for the appropriate dynamic specification, this study, first, performs unit roots tests on the variables. The examination of stationarity or non-stationarity in a time series is closely related to the test for unit roots. A number of alternative tests are available for testing whether a series is stationary. Among them, the Augmented Dickey-Fuller (ADF) and the Philips-Person (PP) tests are the most common.

Any time-series analysis starts by checking the order of integration of each variable. If the first difference of a non-stationary variable is stationary, that variable is said to be integrated of order one, I(1). If second differences are required to achieve stationary, then the variable is integrated of order two, I(2). A Simple regression should be carried out on variables of the same order of integration. If the individual variable is $\mathrm{y}_{\mathrm{t}}$, the general form of ADF test can be written as follows:

$$
\Delta y_{t}=\alpha y_{t-1}+\sum_{i}^{m} \beta_{i} \Delta y_{t-i}+\delta+\gamma t+\varepsilon_{t} \quad \text { (for levels) }
$$


$\Delta \Delta y_{t}=\alpha \Delta y_{t-1}+\sum_{i}^{m} \beta_{i} \Delta \Delta y_{t-i}+\delta+\gamma t+\varepsilon_{t} \quad$ (for first diferences)

where $\mathrm{m}$ is the number of lags and $\mathrm{t}$ is time. The lag lengths $(\mathrm{m})$ should be relatively small in order to save degrees of freedom, but large enough not to allow for the existence of autocorrelation in $\varepsilon_{\mathrm{t}}$. $\varepsilon_{\mathrm{t}}$ represents a sequence of uncorrelated stationary error terms with zero mean and constant variance. Having determined the appropriate value of significance, we test $\mathrm{H}_{0}: \alpha=0$ versus $\mathrm{H}_{\mathrm{a}}: \alpha<0$. Rejection of $\mathrm{H}_{0}$ means that $\mathrm{y}_{\mathrm{t}}$ is $\mathrm{I}(0)$ while acceptance implies that it is integrated of order (1).

The critical values are chosen on the basis of the degrees of freedom and taken from MacKinnon-Hang-Michelis (1999). If the ADF statistic is smaller than the critical value (in absolute terms), the hypothesis of non-stationary cannot be rejected. It concludes that the series is non-stationary. Hence, it contains a unit root. If the ADF statistic is larger than the critical value, the series is stationary. The ADF test equation is re-run with different lag lengths, and including constant and trend, or only constant, or only trend.

There are several alternative criteria for finding the best model and appropriate lag lengths. Some of the commonly used criterions are the Likelihood ratio test (LR), the Akaike Information Criterion (AIC), and the Schwarz Information Criterion (SIC).

\subsubsection{Test for Cointegration}

Cointegration is a statistical implication of the existence of a long-run relationship between variables or co-movement of time-series data. If more variables move closely together, even if they themselves are trended, the difference between them is constant. From a statistical point of view, a long-run relationship means that the variables move together over time so that short-run disturbances from the long-run trend will be corrected (Manning and Andrianacos 1993). In other words, a lack of cointegration indicates that such variables have no long-run relationship. The standard approach to investigate both the long-run relationship and short-run dynamic between economic variables is the cointegration analysis and its error correction model (ECM) representation.

There are several techniques for running cointegration tests. Among them, the Engle-Granger (1987) two step test and the Johansen cointegration test developed by Johansen (1988) and Johansen and Juselius (1990) are the most common techniques. Less error is involved in the Johansen technique, which this study also adopts, because it involves only one step. In the Johansen technique for cointegration, we test for $r$ (the 
maximum number of cointegration relationships) using the maximum eigenvalue statistics $\left(\lambda_{\max }\right)$ and Trace statistics.

\subsubsection{Granger Causality}

The aim of this section is to test whether export Granger causes GDP and to test the causality between exports and investment, and export and manufacturing outputs in Sri Lanka. In economics, Granger (1969) and Sims (1972) developed the operational framework of systematic testing and determination of causal direction. The approach is based on the axiom that the past and present may cause the future but the future cannot cause the past (Granger 1980).

The methodology of the Granger-causality test can be presented as follows. Suppose we test Granger-causality between two variables such as X and Y,

$$
\begin{gathered}
Y_{t}=\sum_{i=1}^{m} \alpha_{i} X_{t-i}+\sum_{i=1}^{m} \beta_{i} Y_{t-i}+u_{1 t} \\
X_{t}=\sum_{i=1}^{m} \lambda_{i} X_{t-i}+\sum_{i=1}^{m} \delta_{i} Y_{t-i}+u_{2 t}
\end{gathered}
$$

where $\mathrm{u}_{1 \mathrm{t}}$ and $\mathrm{u}_{2 \mathrm{t}}$ are serially uncorrelated random disturbances with zero mean. We test to see if $\mathrm{X}$ Granger-causes $\mathrm{Y}$ by using the hypothesis as follows:

$\mathrm{H}_{0}: \alpha_{1}=\alpha_{2}=\alpha_{3}=\ldots \alpha_{\mathrm{m}}=0$ is rejected against the alternative, $\mathrm{H}_{1}:$ not $\mathrm{H}_{0}$

Similarly, we test if $\mathrm{Y}$ Granger causes $\mathrm{X}$ by testing the hypothesis as follows: $\mathrm{H}_{0}^{*}: \delta_{1}=\delta_{2}=\delta_{3}=\ldots \delta_{\mathrm{m}}=0$ is rejected against the alternative, $\mathrm{H}_{1}^{*}:$ not $\mathrm{H}_{0}$

If better predictors of a given series $\mathrm{Y}$ can be obtained by adding to lagged values of $\mathrm{Y}$ current and lagged values of another given variable $\mathrm{X}$, then $\mathrm{X}$ is said to Granger-cause Y.

\subsubsection{Vector Autoregression and Impulse Response Function}

The study formulates a VAR model and IRFs in order to illustrate the dynamic effect of the impact of unitary shocks on these macroeconomic variables under examined. If all the variables are neither stationary at their level nor cointegrated, the first differences of the variables are used to formulate VAR model (Enders 2004). The following mathematical formation of the VAR was employed in this study.

$$
\Delta Y_{t}=A_{1} \Delta Y_{t-1}+\ldots+A_{k} \Delta Y_{t-1}+B \Delta X_{t}+v_{t}
$$


where $Y_{t}$ is a vector of endogenous variable, $X_{t}$ is a vector of exogenous variables. $A_{1}$, $\ldots \mathrm{A}_{k}$, and $\mathrm{B}_{t}$ are matrix of coefficients to be estimated. $v_{t}$ is the vector of innovations that may be contemporaneously correlated but are uncorrelated with their own lagged values and with all of the right-hand side variables. Output and exports are the endogenous variables, while the other variables are employed as exogenous. The best model is the one that minimizes the AIC and the SIC.

Building a VAR model allows us to generate IRFs. Hence, based on the VAR model, the study is then extended to include the IRFs. A disturbance to one variable not only directly affects the particular variable, but is also transmitted to all the other endogenous variables through the dynamic structure of the VAR (Abou-Stait 2005). In general, an IRF illustrates the effect of a one-time shock to one of the innovations on current and future values of the endogenous variables.

\subsection{Data}

The data used in this analyses are obtained from the various issues of the Annual Report of the Central Bank of Sri Lanka. GDP deflator is used to deflate the series. The real values are measured in 1996 prices. The series are transformed into natural logarithm terms. The following time-series are analyzed: real GDP (LRGDP), real exports (LREX), real value of imports (LRIM), real investment expenditure (LRINV), and labor force (LLA). We include imports as a variable since imports may play a significant role in explaining export-led growth. Riezmann et al. (1996) identified imports as an important variable when examining causality between exports and economic growth. Omitting imports may lead to biased results (Riezmann et al. 1996). The data employed are graphically presented in their levels and first differences in Appendix A.

\section{Empirical Results}

Table 1 summarizes the results for unit root test on level and in the first difference of data. For this study, the ADF test was used, which is based on the SIC, while the PP test bandwidth is based on Newey-West. The results indicate that each variable is integrated of order one, I(1). Hence, each variable is stationary in its first difference. 
Table 1 Unit Root Test Results

\begin{tabular}{lllll}
\hline Variable & \multicolumn{2}{l}{ Level (with trend and intercept) } & \multicolumn{2}{l}{ First Difference (with intercept) } \\
\cline { 2 - 5 } & ADF statistic & PP statistic & ADF statistic & PP statistic \\
GDP & $-2.64509(1)$ & $-2.56963(1)$ & $-5.51658^{*}(0)$ & $-5.52767^{*}(2)$ \\
Non-export GDP & $-2.65359(1)$ & $-2.56591(1)$ & $-5.49597^{*}(0)$ & $-5.50755^{*}(2)$ \\
Export & $-2.50282(1)$ & $-2.54537(2)$ & $-6.15241^{*}(0)$ & $-6.14983^{*}(2)$ \\
Import & $-2.46627(1)$ & $-2.64902(1)$ & $-6.44883^{*}(0)$ & $-6.46288^{*}(5)$ \\
Investment & $-1.98231(0)$ & $-2.13754(1)$ & $-6.01710^{*}(0)$ & $-6.01476^{*}(4)$ \\
Employment & $-2.47536(0)$ & $-2.53901(1)$ & $-6.65873^{*}(0)$ & $-6.69782^{*}(3)$ \\
\hline * 1\% critical value & -4.19234 & -4.186481 & -3.59662 & -3.59662 \\
$5 \%$ critical value & -3.52079 & -3.51809 & -2.93316 & -2.93316 \\
\hline
\end{tabular}

The Johansen cointegration test results are presented in Table 2. On the basis of the results of cointegration tests, we fail to reject the null hypothesis of no cointegration between the macroeconomic variables under consideration at 5\% significance level. Hence, the study suggests that there is no cointegration relation between under studied variables in Sri Lanka.

Table 2 Johansen Cointegration Test Results: LRGDP, LREX, LRIM, LRINV, LLA

\begin{tabular}{lllll}
\hline \multirow{2}{*}{$\begin{array}{c}\text { Number of } \\
\text { cointegrating vectors }\end{array}$} & \multicolumn{3}{c}{$\lambda_{\text {Trace }}$} & \multicolumn{2}{c}{$\lambda_{\text {Max }}$} \\
\cline { 2 - 5 } & Statistics & $\mathrm{C}(5 \%)$ & Statistics & $\mathrm{C}(5 \%)$ \\
\hline $\mathrm{r}=0$ & 56.117 & 69.819 & 26.844 & 33.877 \\
$\mathrm{r} \leq 1$ & 29.273 & 47.856 & 13.989 & 27.584 \\
$\mathrm{r} \leq 2$ & 15.284 & 29.797 & 9.765 & 21.132 \\
$\mathrm{r} \leq 3$ & 5.519 & 15.495 & 4.884 & 14.256 \\
$\mathrm{r} \leq 4$ & 0.636 & 3.842 & 0.636 & 3.842 \\
\hline
\end{tabular}

Note: Critical values used are taken from MacKinnon-Hang-Michelis (1999)

We perform the bivariate Granger causality analyses to test different casual relationships among the variables. Since the series are non-stationary for the levels of the variables, this study proceeds with the Granger test using the variables in their stationary forms (their first differences in this case) without incurring in the problem of the spurious regression. Results of the bi-variate analysis are presented in Table 3 . The AIC and the SIC are used to choose the lag structure. 
Table 3 Ganger Causality Test Results

\begin{tabular}{|c|c|c|c|c|}
\hline & Null Hypothesis & Obs. & F-statistic & Probability \\
\hline 1 & DLREX does not Granger cause DLRGDP & 44 & 0.00277 & 0.93829 \\
\hline 2 & DLRGDP does not Granger cause DLREX & 44 & 0.88692 & 0.35211 \\
\hline 3 & DLREX does not Granger cause DLRINV & 44 & 1.66616 & 0.20437 \\
\hline 4 & DLRINV does not Granger cause DLREX & 44 & 0.43358 & 0.51411 \\
\hline 5 & DLREX does not Granger cause DLLA & 44 & 0.04207 & 0.83856 \\
\hline 6 & DLLA does not Granger cause DLREX & 44 & 1.66028 & 0.20516 \\
\hline 7 & DLREX does not Granger cause DLRM & 44 & 5.60898 & $0.02293 * *$ \\
\hline 8 & DLRM does not Granger cause DLREX & 44 & 0.09749 & 0.75653 \\
\hline 9 & DLRGDP does not Granger cause DLRINV & 44 & 1.94366 & 0.17116 \\
\hline 10 & DLRINV does not Granger cause DLRGDP & 44 & 0.54765 & 0.46367 \\
\hline 11 & DLRGDP does not Granger cause DLRM & 44 & 0.01607 & 0.89977 \\
\hline 12 & DLRM does not Granger cause DLRGDP & 44 & 0.02694 & 0.87048 \\
\hline 13 & DLRGDP does not Granger cause DLLA & 44 & 0.82697 & 0.36874 \\
\hline 14 & DLLA does not Granger cause DLRGDP & 44 & 0.63541 & 0.43020 \\
\hline 15 & DLRINV does not Granger cause DLRM & 44 & 0.76898 & 0.38590 \\
\hline 16 & DLRM does not Granger cause DLRINV & 44 & 3.70824 & $0.06146^{* * *}$ \\
\hline 17 & DLRINV does not Granger cause DLLA & 44 & 0.40048 & 0.53054 \\
\hline 18 & DLLA does not Granger cause DLRINV & 44 & 0.11954 & 0.73039 \\
\hline 19 & DLRM does not Granger cause DLLA & 44 & 0.18998 & 0.66534 \\
\hline 20 & DLLA does not Granger cause DLRM & 44 & 2.41107 & 0.12856 \\
\hline
\end{tabular}

$* *$ at $5 \%$ critical value; $* * *$ at $10 \%$ critical value

As displayed in Table 3, no statistical evidence is found to suggest that the real exports Granger cause the real GDP or vice versa. Nevertheless, at 5\% significance level we suggest that real exports Granger cause real imports. The real imports also Granger cause the real investment at $10 \%$ level of significance. Though these findings do not provide direct support for the causal relationship between exports and GDP or the ELG hypothesis, the exports Granger cause imports and further imports Granger cause investment (Table 3).

The findings are reasonably interesting for further research on the ELG hypothesis by looking at export compositions and economic structure in the country. This may involve a long process that we could not capture here. However, from a policy point of view, it is suggested that some institutional bottlenecks and or structural problems including tariff reforms ${ }^{4}$ might well explain the failure of the ELG hypothesis

${ }^{4}$ For example, while promoting the production of exports, the government should remove tariffs to create an open market. In 1990, the average tariff percentage in Sri Lanka was about 28 percent, though by 2002 that percentage had decreased to 18 per cent. 
in Sri Lanka. Exports may increase foreign earnings and allow increases in the capital and intermediate imports and thus, result in the growth of GDP, as described in Section 3 of this study. There might be a bottleneck in this latter process. Therefore, rather than rejecting the ELG hypothesis and export-oriented policies, the country might cautiously need to look at its structural problems.

We also run the same tests by using real GDP without exports (non-export GDP), instead of GDP with exports, (Johansen cointegrtion test results are presented in Appendix C.II results are not reported here), and find the similar outcome and the same conclusion. This study further performs the same analyses employing real industrial exports instead of real total input ${ }^{5}$, and finds no different results (Johansen cointegrtion test results are presented in Appendix C.III). It further reinforces our argument for the non-validity of the ELG hypothesis in the case of Sri Lanka.

Appendix B shows the results of IRFs. The aim is to examine the impact of the outcome of introducing a shock to the system. Introducing a positive shock to the exports, there is no response from other variables, GDP, investment and imports. In the case of GDP, a positive response only from exports is seen, but dies out suddenly. Then introducing a positive shock to investment, a positive response can be observed from both exports and GDP. Finally, positive shocks to imports lead a negative response from exports and a positive response from both GDP and investment. All appears to be died out shortly. This also underpins our previous conclusion that there is no significant impact of exports on the economic growth in Sri Lanka.

\section{Concluding Remarks and Policy Implications}

The study examines the validity of the ELG hypothesis for the case of Sri Lanka. We employed the cointegration test, the Granger causality test, a VAR and IRFs and included previously omitted relevant variables. The study carried out the analyses beyond the traditional two-variable method of testing the ELG using five macroeconomic variables; namely, GDP, exports, imports, investment and labor. The findings of the study fail to support the ELG hypothesis. The lack of support for the ELG hypothesis casts some doubt on the efficiency of the designed policies to stimulate economic growth by promoting the export sector.

Nevertheless, there might be some structural and institutional problems, which obstruct the export-led growth process in the case of Sri Lanka. For example, uncertainty in the political environment, low availability and high prices of basic economic infrastructure facilities such as telephone, and the poor transport network, electricity, an unfriendly regulatory environment including bribery and corruption may result in hampering economic growth in the country. Significant infrastructure development is needed before the export sector development and economic

${ }^{5}$ It is redone for the period of 1973-2005 due to limited availability of data. 
development in general could occur. All of these factors also slow down growth of exports. One should integrate these aspects when analyzing the ELG hypothesis and interpreting the results.

The study also does not take into account the relationship between export growth and productivity growth. Future studies in these respects would be worthwhile. It requires a compressive data set, which is also one of the limitations of this study. As Balaguer and Cantavella-Jorda (2004) recently argue, the structural transformation in export composition also becomes a key factor for economic development. It is also interesting to investigate the role played by the composition of exports in explaining economic growth.

Though several structural changes have been taken place in Sri Lanka in different stages, still, there are some unresolved structural problems such as inefficient public sector, inflexible and high public expenditure, tariff reforms, labor regulation and educational reforms. They also should be addressed in future studies on the ELG hypothesis. 


\section{References}

Abhayaratne, A.S.P, 1996. Foreign Trade and Economic Growth Evidence from Sri Lanka, 1962-1992, Applied Economics Letters, 3: 567-570

Abou-Stait, F, 2005. Are Exports the Engine of Economic Growth? An Application of Cointegration and Causality Analysis for Egypt, 1977-2003, Economic Research Working Paper No. 76, African Development Bank.

Ahmad J, and Kwan, A.C.C, 1991. Causality between Exports and Economic Growth, Economic Letters, 37: 243-8

Awokuse, T.O, 2003. Is the Export-Led Growth Hypothesis Valid for Canada, Canadian Journal of Economics, 36 (1): 126-36

Balaguer, M, and Cantavella-Jorda, M., 2004. Structural Changes in Exports and Economic Growth: Cointegration and Causality Analysis, Applied Economics, 36: $473-77$

Balassa, B., 1978, 'Exports and Economic Growth: Some Additional Evidence', Journal of Development Economics 5: 181-89

-----, 1985. 'Exports, Policy Choices and Economic Growth in Developing Countries after the 1973 Oil Shock, Journal of Development Economics 18: 23-35

Bewley, R, and Yang, M, 1996. On the Size and Power of the System tests for Cointegration, In M. McAleer et al, (eds) Proceedings of Econometric Society Australasian Meetings, 3, 1-20, Perth, Australia.

Boltho. A., 1996. Was Japanese Growth Export-led? Oxford Economic Papers 48:41532

Chow, P.C.Y., 1987. Causality between Export Growth and Industrial Development: Empirical Evidence from the NICs, Journal of Development Economics 26: $55-$ 63

Darrat, A.F, 1987. Are Exports an Engine of Growth? Another Look at the Evidence, Applied Economics, 19: 277-83

Doyle, E, 1998. Export-Output Causality: the Irish Case 1953-93, Atlantic Economic Journal 26(2): 147-161

Ekanayake, E.M., 1999. 'Export and Economic Growth in Asian Developing Countries: Cointegration and Error-Correlection Models', Journal of Economic Development, 24 (2): 43-54

Enders, W, 2004. Applied Econometric Time Series, Second Edition, Wiley, Hoboken

Engle, R.F., and Granger, C.W.J., 1987. Cointegration and Error Correction; Representation, Estimation and Testing, Econometrica, 55, 251-76 
Feder, G, 1983. On Export and Economic Growth, Journal of Development Economics, $12(1 / 2): 59-73$

Fernando,L and Colombage,S., 2002. Exports and Economic Growth in South Asia, A study prepared for the South Asia Network of Economic Research Institutes

Ghartey, E.E, 1993. Causal Relationship between Exports and Economic Growth: Some Empirical Evidence in Taiwan, Japan, and the U.S., Applied Economics, 25: $1145-52$

Ghatak, Milner, C., and Utkulu, U, 1997. Exports, Export Composition and Growth: Cointegration and Causality Evidence for Malaysia, Applied Economics, 29: 213-23

Giles, J.A, and Willams, C.L, 1999. Export-led Growth: A Survey of the Empirical Literature and some Noncasuality Results, Econometric Working Paper, EWP9901, Department of Economics, University of Victoria

Granger, C.W., 1980, Testing for Causality, Journal of Economic Dynamics and Control, 2: 329- 352

Grossman, G.M, and Helpman E, 1991, Innovation and Growth in the Global Economy, Cambridge, MA: MIT Press.

Hatemi-J, A, and Lrandoust, M, 2000. Time Series Evidence for Balassa's Export-led Growth Hypothesis, Journal of International Trade and Economic Development, 9(3): 355-65

Helpman, E, and Krugman, P, 1985. Market Structure and Foreign Trade, Cambridge, MA: MIT Press.

Islam, M.N, 1998. Export Expansion and Economic Growth: Testing for Cointegration and Causality, Applied Economics, 30: 415-25

Jin J.C, 1995. Export-led Growth and the Four Little Dragons, Journal of International Trade and Economic Development, 4: 203-15

Inder, B., 1993, Estimating Long-run Relationships in Economics: A Comparison of different Approaches, Journal of Econometrics, 57: 53-68

Johansen, S., 1988. Determinants of Cointegration Ranks in the Presence of a Linear Trend, Oxford Bulletin and Economics and Statistics, 54: 383-90

Johansen, S., and Juselius, K, 1990. Maximum Likelihood Estimation and Inference Cointegration with Application to the Demand of Money, Oxford Bulletin and Economics and Statistics, 56: 169-210

Jung W.S, and Marshall, P.J, 1985. Exports, Growth and Causality in Developing Countries, Journal of Development Economics, 18(1): 1-12

Kravis, I.B., 1970, 'Trade as a Handmaiden of Growth: Similarities between the Nineteen and Twentieth Centuries', Economic Journal, 30(320): 850-872 
Kunst, R.M, and Marin, D, 1989. Notes on Exports and Productivity: A Casual Analysis, The Review of Economics and Statistics, 71: 699-703

Love, J, 1992, Export Instability and the Domestic Economy; Questions of Causality, Journal of Development Studies, 28(4); 735-42

MacKinnon, J.G., Haug, A.A., and Michelis, L., 1999, Numerical Distribution Functions of Likelihood Ratio Tests for Cointegration, Journal of Applied Econometrics, 14: 563-77

Manning, L. M., and Adriacanos, D., 1993, Dollar Movements and Inflation: a Cointegration Analysis, Applied Economics, 25. 1483-1488

Mckinnon, R, 1964. Foreign Exchange Constraint in Economic Development and Efficient Aid Allocation, Economic Journal, 74: 388-409

Michaely, M., 1977, Exports and Growth: An Empirical Investigations', Journal of Development Economics 4: 49-53

Moosa, I,A, 1999. Is the Export Growth-led Hypothesis Valid for Australia? Applied Economics, 31: 903-906

Oxley, L., 1993. Cointegration, Causality and Export-Led Growth in Portugal, 18651985, Economics Letters, 43: 163-6

Poon, J.P 1995. 'Export Expansion, Economic Growth and economic Development Revisited', Journal of Economic Development, 20(1): 75-90

Ram, R., 1985, 'Exports and Economic Growth: Some Additional Evidence', Economic Development and Cultural Changes, 33(2):415-425

-------, 1987. Exports and Economic Growth in Developing Countries: Evidence from Time-series and Cross-section Data, Economic Development and Cultural Change, 33: 415-25

Riezman, R., Whiteman, C.H., and Summers, P.M., 1996. The Engine of Growth or its Handmaiden? A Time Series Assessment of Export-Led Growth, Empirical Economics, 21: 77-110

Shan, J., and Sun, F., 1998. 'On the Export-led Growth Hypothesis: the Econometrics Evidence from China, Applied Economics 30: 1055-65

Sharma, A, and Panagiotidis, T., 2005. An Analysis of Exports and Growth in India: Cointegration and Causality Evidence (1971-2001), Review of Development Economics, 9: 232-48

Shirazi N.S. and Abdul Manap T.A., 2005. Export-led growth Hypothesis: Further Econometric Evidence from South Asia, The Developing Economies, XLIII-4

Sims, C.A, 1972. Money, Income and Causality, The American Economic Review, 62: 540-552

Sun H, and Parikh, A., 2001, Exports and Regional Economic Growth in China, Regional Studies, 35 (3): 187-196

Thornton, J, 1996. Cointegration, Causality and Export-led Growth in Mexico, 18951992, Economics Letters, 50: 413-6 
Toda, H.Y, 1994. Finite Sample Properties of Likelihood Ratio Tests for Cointegration Ranks when Linear Trends are Present, Review of Economics and Statistics, 76: 66-79

Toda, H.Y, and Yamamoto, T., 1995. Statistical Inference in Vector Autoregressions with Possibly Integrated Processes, Journal of Econometrics, 66: 225-50

Tyler, W, 1981. Growth and Export Expansion in Developing Countries: Some Empirical Evidence, Journal of Economic Development, 9, 121-30

Xu, Z, 1996. On the Causality between Export Growth and GDP Growth: Empirical Evidence, Review of International Economics, 4(6): 172-84

Yaghmalan, B., and Ghorashi, R., 1995. 'Export Performance and Economic Development: an empirical Analysis', American Economist, 9 (2): 37-46 


\section{Appendix A.I: Level of Time Series: LRGDP, LREX, LRIM, LRINV, LLA}
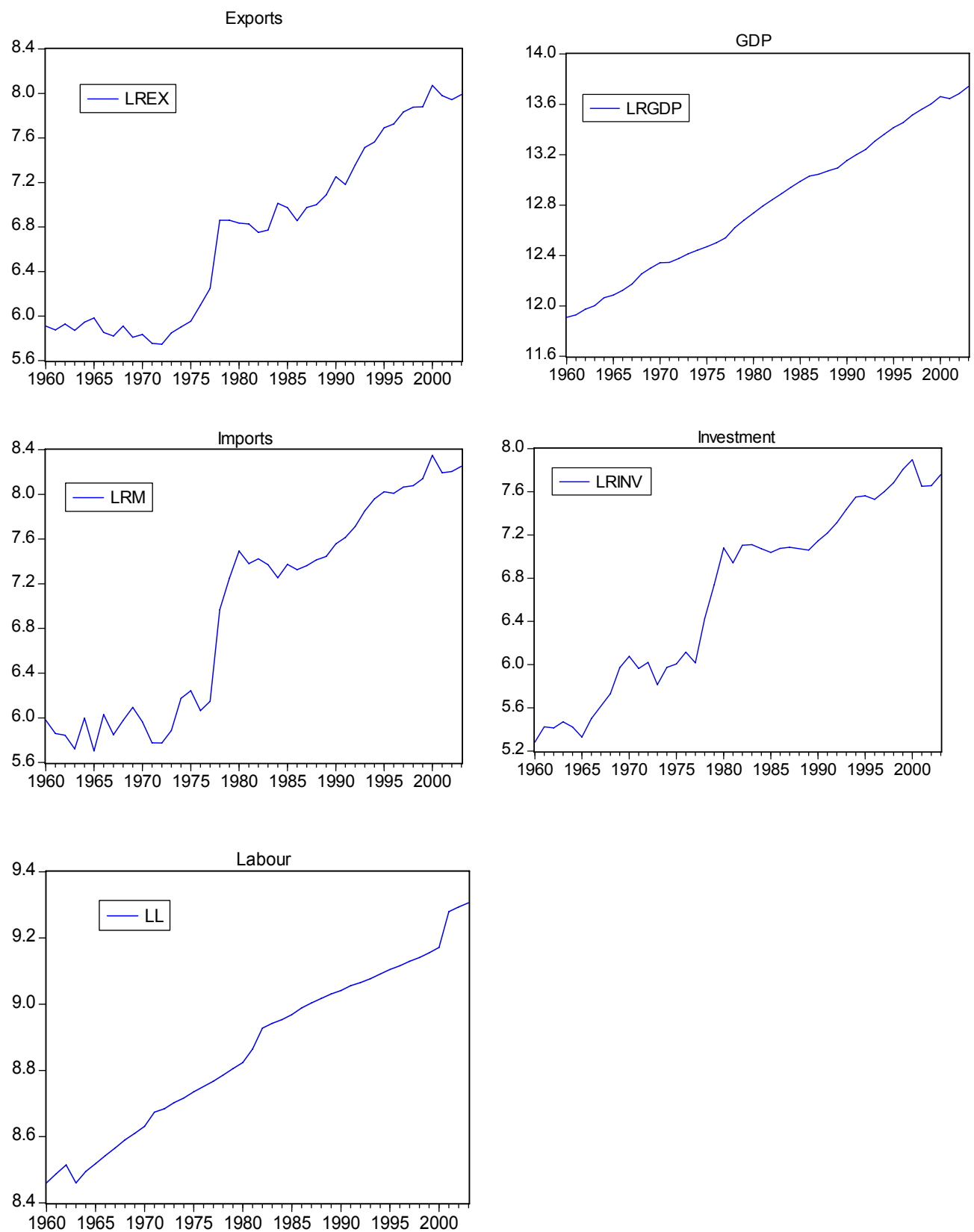
Appendix A.II: First Differences of Time-series: LRGDP, LREX, LRIM, LRINV, LLA
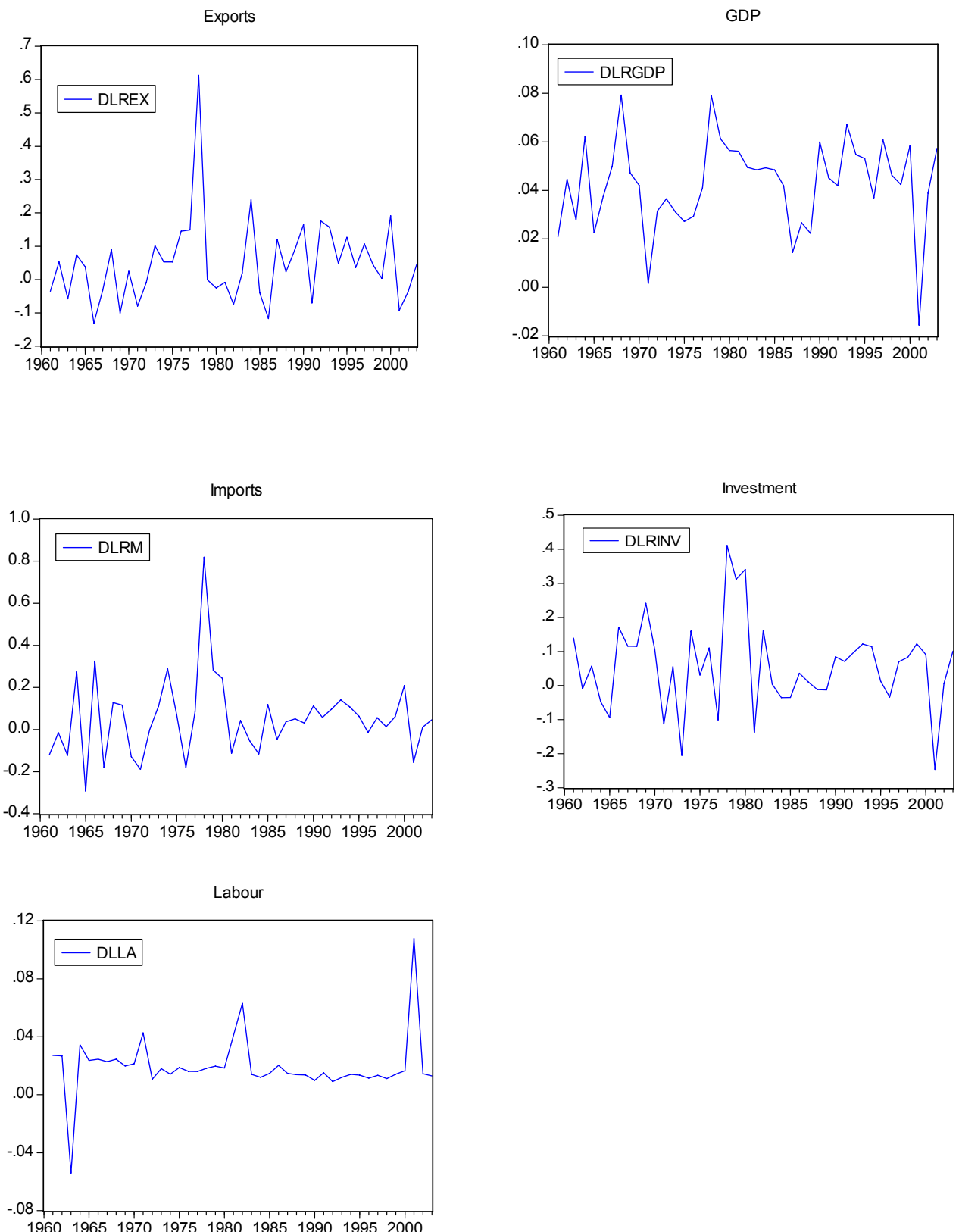

92 


\section{Appendix B: Impulse Response Functions (IRFs)}
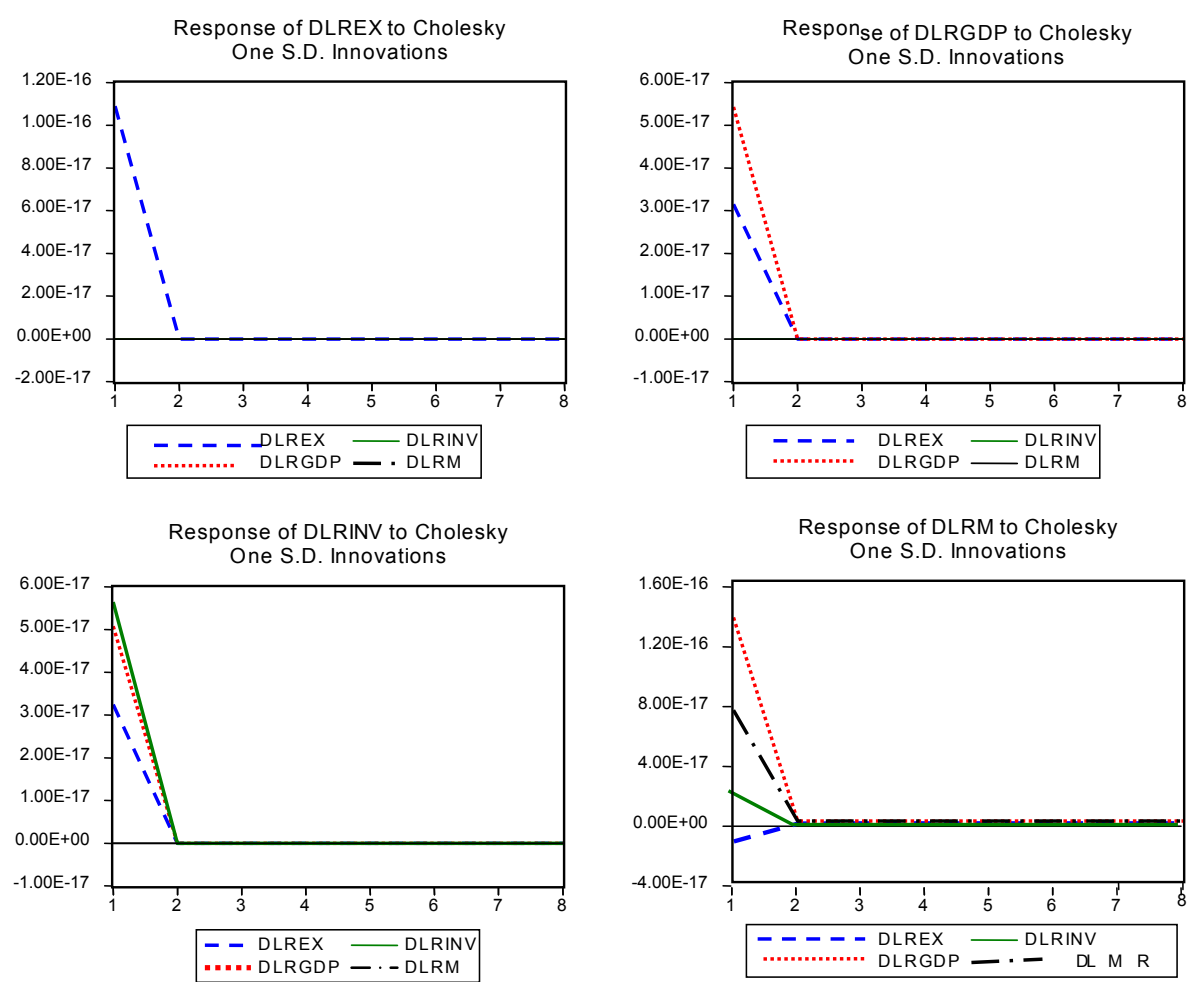
Appendix C.I

Johansen Cointegration Test Results (1960-2005): Non-export LRGDP, LREX, LRIM, LRINV, LLA

\begin{tabular}{|c|c|c|c|c|}
\hline \multirow{2}{*}{$\begin{array}{l}\text { Number of } \\
\text { cointegrating vectors }\end{array}$} & \multicolumn{2}{|l|}{$\lambda_{\text {Trace }}$} & \multicolumn{2}{|l|}{$\lambda_{\operatorname{Max}}$} \\
\hline & Statistics & C (5\%) & Statistics & $\mathrm{C}(5 \%)$ \\
\hline $\mathrm{r}=0$ & 56.1399 & 69.819 & 26.853 & 33.877 \\
\hline$r \leq 1$ & 29.2870 & 47.856 & 13.992 & 27.584 \\
\hline$r \leq 2$ & 15.2923 & 29.797 & 9.766 & 21.132 \\
\hline$r \leq 3$ & 5.5296 & 15.495 & 4.894 & 14.256 \\
\hline$r \leq 4$ & 0.6361 & 3.842 & 0.636 & 3.842 \\
\hline
\end{tabular}

Note: Critical values used are taken from MacKinnon-Hang-Michelis (1999)

\section{Appendix C.II}

Johansen Cointegration Test Results (1973-2005): LRGDP, LRIEX (real industrial export), LRIM, LRINV, LLA

\begin{tabular}{lllll}
\hline \multirow{2}{*}{$\begin{array}{l}\text { Number } \\
\text { cointegrating vectors }\end{array}$} & of & $\lambda_{\text {Trace }}$ & & $\lambda_{\text {Max }}$ \\
\cline { 2 - 5 } & Statistics & C (5\%) & Statistics & C (5\%) \\
\hline $\mathrm{r}=0$ & $70.526^{* *}$ & 69.819 & 33.265 & 33.877 \\
$\mathrm{r} \leq 1$ & 37.262 & 47.856 & 19.458 & 27.584 \\
$\mathrm{r} \leq 2$ & 17.804 & 29.797 & 9.505 & 21.132 \\
$\mathrm{r} \leq 3$ & 8.299 & 15.495 & 6.359 & 14.256 \\
$\mathrm{r} \leq 4$ & 1.939 & 3.842 & 1.939 & 3.842 \\
\hline
\end{tabular}

Note: Critical values used are taken from MacKinnon-Hang-Michelis (1999)

** denotes rejection of the hypothesis at the 0.05 level. 